\title{
Differences in the Perception of Birth Policies by the Middle aged and the Elderly in China
}

\author{
Yun-Jeong Kim, Shuhu Chen
}

\begin{abstract}
Because of the drastic changes in China's birth policies, it is anticipated that the middle-aged and the elderly would view the policy of 'one household, two children' differently. As such, this study seeks to identify such a difference between the middle-aged and the elderly. There were 320 sets of data for the elderly generation and 305 for the middle-aged generation used for the final analysis. The study shows that, unlike the elderly generation, the middle-aged group has a negative perception towards the 'one household, two children' policy. Second, for the elderly generation of China, there was a significant difference in their perception towards the 'one household, two children' policy and 'preferred gender of children' depending on what the gender of the respondent's child was. The elderly with only daughters had a rather negative perception towards the policy, and their preferred gender for children was also 'sons'. Third, middle aged people with daughters had a more positive perception towards the policy.
\end{abstract}

Keywords: Birth policy, One household two children, Generation gap, Preferred gender of children, Fertility

\section{INTRODUCTION}

$\mathrm{B}$ irth rates have become a difficult issue in the 21 st century, because more than half of the world's countries have been recording a low birth rate, not just in developed countries but also in developing countries. Low birth rates lead to accelerated aging of the population and are directly linked to a reduced labor resource for the country. It is an important issue linked with the very existence of a country.

China's birth policy has been undergoing change in response to population change [1]. Because of wars and natural disasters that had continued for over 100 years, China in 1949 adopted a policy that encouraged giving birth. The population in 1953 was 587 million, with a birth rate of $37 \%$ and death rate of $14 \%$, leading to a natural increase rate of $23 \%$. Since then, there has been an annual increase in population of about 12 to 13 million, that is population growth rate of $20 \%$.

A well-known Chinese populist, Ma In Chu, announced the "New Population Theory" in 1957 and argued that the quality of the population can be improved by controlling the size of the population. Only in the 1960s did the Chinese government take population growth as a serious issue and started to deter birth and encourage people to delay marriage [2].

Revised Manuscript Received on July 22, 2019.

Yun-Jeong Kim, Department of Health, Counseling and Welfare, Hanseo University, Seosan City, South Korea. Email: twoyun21@hanmail.net

Shuhu Chen*, Department of History and Sociology, Anhui Normal University, Wuhu City, People's Republic of China. Email: chenshuhu203@hotmail.com
In the early 1970s, the population had grown from 540 million to 830 million, posing a great burden on national development. In 1980, a one-child policy was promoted. In 1982, the basic stance of the government was to control child birth, but this was difficult to execute, because many Chinese were still holding onto the idea that having more children was a better way to prepare for one's older age [3]. If birth-control policies had not taken effect, the current Chinese population would have exceeded 1.7 billion [4]. After the "Law on Population and Family Planning" was passed in 2001, the government allowed couples to have a second baby if both the mother and the father were an only child. In 2013, a second baby was allowed for cases where only one of the parents was an only child. Starting on January 1, 2016, having a second baby was legalized for all. That is an 'one household, two children' policy is being actively promoted. This is partly because of the rapid aging of the population.

In 2017, those aged 60 or older totaled 240 million in China, or $17.3 \%$ of the population. Those aged 65 or older accounted for $11.4 \%$ or 158 million [5]. The policy to full on approve of having two children was not just a turnaround, but was considered to ease the pressure on an aging population. Although the birth rate grew in the first year since the policy was launched in 2016, in 2017 it fell back again [5]. This had been anticipated. Yang Jung Dang, a Chinese populist, argued that China has become a society where people are reluctant to give birth. That is, the desire for childbirth across Chinese society had been dampened, not just because of the change in how childbirth was viewed, but also because of the financial burden. With urbanization and industrialization came changes in life style and living environments. The cost of living, education, job search, and medical care also increased [6]. Moreover, the traditional social structure weakened, and new production methods and market economy elements had already arrived, leading to the Chinese valuing economic prosperity more [7].

Based on the multiple estimations, our main conclusion is that China's recent fertility level is above 1.6, and the implementation of the two-child policy has significantly increased the fertility level. Reduction in the TFR for first birth is largely driven by the tempo effect of delayed age at marriage and birth, while the marked increase in the TFR for second birth reflects the birth-bunching effect due to the newly implemented two-child policy [8]. The decline of the first birth also led to a relative increase in the share of the second birth, so the increase in the proportion of the second births born in recent years reflects both

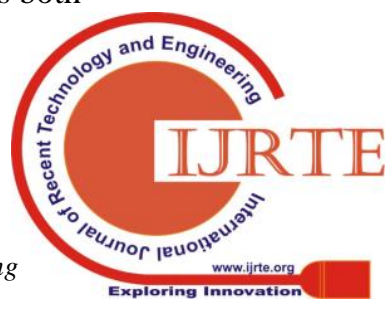


the adjustment effect of fertility policy and the decline in the fertility level of first birth. Therefore, it is extremely important to improve the fertility level of first birth, otherwise the policy adjustment can only increase the number of second birth born in the short term, and then the overall fertility level will be reduced thereafter. As a matter of fact, despite the adjustment of the fertility policy, the risk of too low fertility still persists. This must arouse the high vigilance of the government authorities and the whole society [9]. There are delays in fertility bloom in China. The total birth bloom age is 20-34 years old, and the period effect affects the second child fertility rate. The fertility rate of the lately birth cohort population did not decrease [10]. Based on the census 2010 of China and parity progression method, this paper has made several simulation scenarios and pointed out that under the strengthen condition of inhibition fertility, the population strategy target of stabilization the fertility level at 1.8 cannot be reached. The long-term fast population aging cannot be avoided. The low fertility trap, fast aging for labor force and structure imbalanced problems will be seriously and urgent in the future $[11,12]$.

Because of the drastic changes in China's birth policies, it is anticipated that the middle-aged and the elderly would view the policy of 'one household, two children' differently. As such, this study seeks to identify such a difference between the middle-aged (ages 40-59) and the elderly (aged 60 or older). Specifically, the following will be reviewed: First, what are the differences between generations in their views on the 'one household, two children' policy? Second, how does this perception differ depending on the gender of the group's own children?

\section{METHOD}

\section{A. Study Subjects and Data Collection}

The subjects of this study were middle-aged people, aged 40 to 60 years, as well as the elderly aged over 60 years. Both groups were living in China. The survey was conducted from June to August 2017 with the elderly subjects in Shanghai, Xuzhou, Hefei, Suzhou, Chuzhou, Wuhu, Maanshan, and Lingbi Xian. For the middle-aged generation, the survey was conducted with the parents of the students in $\mathrm{H}$ University by WECHAT.QQ using cellphones or with the parents of the students in Huangshan University and Guangxi Teachers University by requesting a survey. There were 320 sets of data for the elderly generation and 305 for the middle-aged generation used for the final analysis.

\section{B. Measurement}

For perception of childbirth policies, the perception on the 'one household, two children' policy was measured on a fivepoint Likert scale which was converted to a three point system in the analysis. Questions were also asked about the change in direction of the current child birth policy, whether it should be one household, one child, or one household, two children, whether there should be no limits to the number of children, or whether they had never thought about this issue. Moreover, a question was added on how many children they see as ideal, and their preferred gender (son, daughter or does not matter).

\section{Sociodemographic Characteristics}

In the elderly group, women accounted for $44.9 \%$ and men $55.1 \%$. The average age was 69.06 years. Those who had graduated from university or higher accounted for the largest share at $28.7 \%$. The most common profession was public officer at $38.2 \%$. In terms of area of residence, $46.1 \%$ lived in a large city, $41.2 \%$ in a mid-sized city, and $12.5 \%$ in a rural area. For the middle-aged group, $60.0 \%$ were women, and $40.0 \%$ were men. The average age was 48.42 years. Those who had graduated from university or higher accounted for the largest share at $55.6 \%$. The most common profession was public officer at $43.9 \%$. In area of residence, $64.4 \%$ lived in a mid-sized city, $21.5 \%$ lived in a large city, and $14.1 \%$ lived in a rural area.

\section{Analysis Method}

SPSS Win 21.0 was used for frequency and cross-tab analysis.

\section{RESULTS AND DISCUSSION}

\section{A. Difference in perception of child-birth policy between the middle-aged and the elderly in China}

Although there was a difference in perception between the two generations about the 'one household, two children policy' and 'changes in the current childbirth policy', there was no difference in 'the ideal number of children' and 'preferred gender of the child' (Table- I).

Unlike the elderly generation, the middle-aged group had a higher share of people viewing the government's constraints on the number of children as negative. That is, whereas $70.9 \%$ of the elderly generation saw the 'one household, two children' policy as desirable, $53.7 \%$ of those in the middle-aged group did not see it as desirable saw it as just ok. Those who thought that there should be no limits to how many children a couple can have also accounted for $46.8 \%$ in the middle-aged group. However, the middle-aged group did not think that the number of children per household should be two or more. Those who thought that two children were ideal accounted for $77.5 \%$ and $78.0 \%$ in the elderly group and the middle-aged group, respectively. Nor was there a significant difference in the responses given for 'no specific preference for the gender of the child' as the two groups showed this response rate as $74.4 \%$ and $75.1 \%$, respectively.

Table- I: Difference in Perception of Child Birth Policies between the Middle-aged group and the Elderly

$\langle\mathrm{N}=525\rangle$

\begin{tabular}{|c|c|c|c|c|}
\hline & & $\begin{array}{c}\text { Old } \\
\text { aged }\end{array}$ & $\begin{array}{c}\text { Middle } \\
\text { aged }\end{array}$ & Chi-square \\
\hline \multirow{3}{*}{$\begin{array}{l}\text { One } \\
\text { household, } \\
\text { two children } \\
\text { policy }\end{array}$} & No desirable & $\begin{array}{c}51 \\
15.9 \%\end{array}$ & $\begin{array}{c}60 \\
29.3 \%\end{array}$ & \multirow[t]{3}{*}{$31.876^{* * * *}$} \\
\hline & Just as ok & $\begin{array}{c}42 \\
13.1 \% \\
\end{array}$ & $\begin{array}{c}50 \\
24.4 \% \\
\end{array}$ & \\
\hline & Desirable & $\begin{array}{c}227 \\
70.9 \%\end{array}$ & $\begin{array}{c}95 \\
46.3 \%\end{array}$ & \\
\hline \multirow{2}{*}{$\begin{array}{l}\text { Changes in } \\
\text { the current } \\
\text { childbirth } \\
\text { policy }\end{array}$} & $\begin{array}{l}\text { One household } \\
\text { one children }\end{array}$ & $\begin{array}{c}7 \\
2.2 \%\end{array}$ & $\begin{array}{c}3 \\
1.5 \%\end{array}$ & \multirow[t]{2}{*}{$33.750 * * *$} \\
\hline & $\begin{array}{l}\text { One household } \\
\text { two children }\end{array}$ & $\begin{array}{c}156 \\
48.8 \%\end{array}$ & $\begin{array}{c}50 \\
24.4 \%\end{array}$ & \\
\hline
\end{tabular}




\begin{tabular}{|c|c|c|c|c|}
\hline & $\begin{array}{l}\text { No limits to how } \\
\text { many children a } \\
\text { couple }\end{array}$ & $\begin{array}{c}90 \\
28.1 \%\end{array}$ & $\begin{array}{c}96 \\
46.8 \%\end{array}$ & \\
\hline & No think about & $\begin{array}{c}67 \\
20.9 \%\end{array}$ & $\begin{array}{c}56 \\
27.3 \%\end{array}$ & \\
\hline \multirow{4}{*}{$\begin{array}{l}\text { Ideal } \\
\text { number of } \\
\text { children }\end{array}$} & 0 & $\begin{array}{c}2 \\
.6 \%\end{array}$ & $\begin{array}{c}0 \\
0.0 \%\end{array}$ & \multirow[t]{4}{*}{1.515} \\
\hline & 1 & $\begin{array}{c}15 \\
4.7 \%\end{array}$ & $\begin{array}{c}8 \\
3.9 \%\end{array}$ & \\
\hline & 2 & $\begin{array}{c}248 \\
77.5 \%\end{array}$ & $\begin{array}{c}160 \\
78.0 \%\end{array}$ & \\
\hline & Over 3 & $\begin{array}{c}55 \\
17.2 \%\end{array}$ & $\begin{array}{c}37 \\
18.0 \%\end{array}$ & \\
\hline \multirow{3}{*}{$\begin{array}{l}\text { Preferred } \\
\text { gender of } \\
\text { the child }\end{array}$} & Son & $\begin{array}{c}53 \\
16.6 \%\end{array}$ & $\begin{array}{c}32 \\
15.6 \%\end{array}$ & \multirow[t]{3}{*}{.085} \\
\hline & Daughter & $\begin{array}{c}29 \\
9.1 \%\end{array}$ & $\begin{array}{c}19 \\
9.3 \%\end{array}$ & \\
\hline & $\begin{array}{c}\text { No specific } \\
\text { preference for } \\
\text { the gender of the } \\
\text { Child } \\
\end{array}$ & $\begin{array}{c}238 \\
74.4 \%\end{array}$ & $\begin{array}{c}154 \\
75.1 \%\end{array}$ & \\
\hline \multicolumn{2}{|r|}{ Total } & $\begin{array}{c}320 \\
100 \%\end{array}$ & $\begin{array}{c}205 \\
100 \%\end{array}$ & \\
\hline
\end{tabular}

$* * * \mathrm{p}<.001$

\section{B. Difference in perception of child- birth policy according to the gender of one's own child}

Elderly group: Since the difference in perception towards childbirth policies across generations was significant, the difference in perception of childbirth policy according to the gender of one' s own child was also analyzed. In the elderly group, there was a significant difference in the perception of 'one household, two children policy' and 'preferred gender of child', according to the gender of their own child (Table- II).

A high percentage of respondents thought the policy was desirable, and the elderly group with just sons who answered 'It's ok' accounted for $23.9 \%$, making it the second most common response, but those who have both sons and daughters or only daughters had 'not desirable' as their response in $12.3 \%$ and $24.7 \%$ of the cases, respectively. For the preferred gender of the child, those who said it did not matter had a high percentage, but those with only sons or with sons and daughters had a preference for sons, whereas those with only daughters had a preference for daughters.

Middle-aged group: For the middle-aged group, there was significant difference in the perception of the 'one household, two children policy' according to the gender of their own children (Table- III).

That is, among middle- aged people with only sons, $40.0 \%$ answered that the policy was not desirable, whereas those with sons and daughters or only daughters responded 'desirable' in $64.3 \%$ and $46.4 \%$ of the cases, respectively. But the differences in the perception towards changes in the current childbirth policy, ideal number of children or preferred gender of children were not significant across different genders of the respondent's own children.

Table- II: Difference in Perception of Childbirth Policies according to the Gender of one's own Child in the Elderly group of China

\begin{tabular}{|c|c|c|c|c|c|c|}
\hline & & Only son & Son + Daughter & Only daughter & No child & Chi-square \\
\hline \multirow{3}{*}{$\begin{array}{l}\text { One } \\
\text { household, } \\
\text { two } \\
\text { children } \\
\text { policy }\end{array}$} & No desirable & $\begin{array}{c}12 \\
13.0 \%\end{array}$ & $\begin{array}{c}16 \\
12.3 \%\end{array}$ & $\begin{array}{c}23 \\
24.7 \% \\
\end{array}$ & $\begin{array}{c}0 \\
0.0 \%\end{array}$ & \multirow[t]{3}{*}{$24.786 * * *$} \\
\hline & Just as ok & $\begin{array}{c}22 \\
23.9 \%\end{array}$ & $\begin{array}{c}10 \\
7.7 \%\end{array}$ & $\begin{array}{c}8 \\
8.6 \%\end{array}$ & $\begin{array}{c}2 \\
40.0 \%\end{array}$ & \\
\hline & Desirable & $\begin{array}{c}58 \\
63.0 \%\end{array}$ & $\begin{array}{c}104 \\
80.0 \%\end{array}$ & $\begin{array}{c}62 \\
66.7 \%\end{array}$ & $\begin{array}{c}3 \\
60.0 \%\end{array}$ & \\
\hline \multirow{4}{*}{$\begin{array}{l}\text { Changes in } \\
\text { the current } \\
\text { childbirth } \\
\text { policy }\end{array}$} & $\begin{array}{l}\text { One household one } \\
\text { Children }\end{array}$ & $\begin{array}{c}0 \\
0.0 \%\end{array}$ & $\begin{array}{c}5 \\
3.8 \%\end{array}$ & $\begin{array}{c}2 \\
2.2 \%\end{array}$ & $\begin{array}{c}0 \\
0.0 \%\end{array}$ & \multirow[t]{4}{*}{10.620} \\
\hline & One household two children & $\begin{array}{c}39 \\
42.4 \% \\
\end{array}$ & $\begin{array}{c}64 \\
49.2 \% \\
\end{array}$ & $\begin{array}{c}51 \\
54.8 \%\end{array}$ & $\begin{array}{c}2 \\
40.0 \%\end{array}$ & \\
\hline & No limits to how many children a couple & $\begin{array}{c}34 \\
37.0 \%\end{array}$ & $\begin{array}{c}30 \\
23.1 \%\end{array}$ & $\begin{array}{c}24 \\
25.8 \%\end{array}$ & $\begin{array}{c}2 \\
40.0 \%\end{array}$ & \\
\hline & No think about & $\begin{array}{c}19 \\
20.7 \%\end{array}$ & $\begin{array}{c}31 \\
23.8 \%\end{array}$ & $\begin{array}{c}16 \\
17.2 \%\end{array}$ & $\begin{array}{c}1 \\
20.0 \%\end{array}$ & \\
\hline \multirow{4}{*}{$\begin{array}{l}\text { Ideal } \\
\text { number of } \\
\text { children }\end{array}$} & 0 & $\begin{array}{c}0 \\
0.0 \%\end{array}$ & $\begin{array}{c}1 \\
.8 \%\end{array}$ & $\begin{array}{c}1 \\
1.1 \%\end{array}$ & $\begin{array}{c}0 \\
0.0 \%\end{array}$ & \multirow[t]{4}{*}{5.681} \\
\hline & 1 & $\begin{array}{c}3 \\
3.3 \%\end{array}$ & $\begin{array}{c}7 \\
5.4 \%\end{array}$ & $\begin{array}{c}5 \\
5.4 \%\end{array}$ & $\begin{array}{c}0 \\
0.0 \%\end{array}$ & \\
\hline & 2 & $\begin{array}{c}67 \\
72.8 \%\end{array}$ & $\begin{array}{c}103 \\
79.2 \%\end{array}$ & $\begin{array}{c}74 \\
79.6 \%\end{array}$ & $\begin{array}{c}4 \\
80.0 \%\end{array}$ & \\
\hline & Over 3 & $\begin{array}{c}22 \\
23.9 \%\end{array}$ & $\begin{array}{c}19 \\
14.6 \%\end{array}$ & $\begin{array}{c}13 \\
14.0 \%\end{array}$ & $\begin{array}{c}1 \\
20.0 \%\end{array}$ & \\
\hline \multirow{3}{*}{$\begin{array}{l}\text { Preferred } \\
\text { gender of } \\
\text { the } \\
\text { Child }\end{array}$} & Son & $\begin{array}{c}17 \\
18.5 \%\end{array}$ & $\begin{array}{c}32 \\
24.6 \%\end{array}$ & $\begin{array}{c}4 \\
4.3 \%\end{array}$ & $\begin{array}{c}0 \\
0.0 \%\end{array}$ & \multirow[t]{3}{*}{$18.610^{* *}$} \\
\hline & Daughter & $\begin{array}{c}7 \\
7.6 \%\end{array}$ & $\begin{array}{c}11 \\
8.5 \%\end{array}$ & $\begin{array}{c}11 \\
11.8 \%\end{array}$ & $\begin{array}{c}0 \\
0.0 \%\end{array}$ & \\
\hline & $\begin{array}{l}\text { No specific preference } \\
\text { for the gender of the } \\
\text { child }\end{array}$ & $\begin{array}{c}68 \\
73.9 \%\end{array}$ & $\begin{array}{c}87 \\
66.9 \%\end{array}$ & $\begin{array}{c}78 \\
83.9 \%\end{array}$ & $\begin{array}{c}5 \\
100.0 \%\end{array}$ & \\
\hline \multicolumn{2}{|l|}{ Total } & $\begin{array}{c}92 \\
100.0 \%\end{array}$ & $\begin{array}{c}130 \\
100.0 \%\end{array}$ & $\begin{array}{c}93 \\
100.0 \%\end{array}$ & 5 & \\
\hline \multicolumn{7}{|c|}{${ }^{*} \mathrm{p}<.01, * * * \mathrm{p}<.001$} \\
\hline
\end{tabular}


Table- III: Difference in Perception of Childbirth Policies according to the Gender of their own Child in the Middle-aged group of China

$<\mathrm{N}=205\rangle$

\begin{tabular}{|c|c|c|c|c|c|c|}
\hline & Only son & Son + Daughter & Only daughter & No child & Chi-square \\
\hline \multirow{3}{*}{$\begin{array}{c}\text { One } \\
\text { household, } \\
\text { two children } \\
\text { policy }\end{array}$} & No desirable & $\begin{array}{c}34 \\
40.0 \%\end{array}$ & $\begin{array}{c}9 \\
21.4 \% \\
\end{array}$ & $\begin{array}{c}16 \\
23.2 \%\end{array}$ & $\begin{array}{c}1 \\
11.1 \%\end{array}$ & \multirow[t]{3}{*}{$14.844^{*}$} \\
\hline & Just as ok & $\begin{array}{c}19 \\
22.4 \%\end{array}$ & $\begin{array}{c}6 \\
14.3 \%\end{array}$ & $\begin{array}{c}21 \\
30.4 \%\end{array}$ & $\begin{array}{c}4 \\
44.4 \%\end{array}$ & \\
\hline & Desirable & $\begin{array}{c}32 \\
37.6 \%\end{array}$ & $\begin{array}{c}27 \\
64.3 \%\end{array}$ & $\begin{array}{c}32 \\
46.4 \%\end{array}$ & $\begin{array}{c}4 \\
44.4 \%\end{array}$ & \\
\hline \multirow{4}{*}{$\begin{array}{l}\text { Changes in } \\
\text { the current } \\
\text { childbirth } \\
\text { policy }\end{array}$} & $\begin{array}{c}\text { One household one } \\
\text { children }\end{array}$ & $\begin{array}{c}1 \\
1.2 \% \\
\end{array}$ & $\begin{array}{c}2 \\
4.8 \% \\
\end{array}$ & $\begin{array}{c}0 \\
0.0 \% \\
\end{array}$ & $\begin{array}{c}0 \\
0.0 \% \\
\end{array}$ & \multirow[t]{4}{*}{11.522} \\
\hline & $\begin{array}{c}\text { One household two } \\
\text { children }\end{array}$ & $\begin{array}{c}25 \\
29.4 \% \\
\end{array}$ & $\begin{array}{c}13 \\
31.0 \% \\
\end{array}$ & $\begin{array}{c}10 \\
14.5 \% \\
\end{array}$ & $\begin{array}{c}2 \\
22.2 \% \\
\end{array}$ & \\
\hline & $\begin{array}{l}\text { No limits to how many } \\
\text { children a couple }\end{array}$ & $\begin{array}{c}37 \\
43.5 \% \\
\end{array}$ & $\begin{array}{c}19 \\
45.2 \% \\
\end{array}$ & $\begin{array}{c}36 \\
52.2 \% \\
\end{array}$ & $\begin{array}{c}4 \\
44.4 \%\end{array}$ & \\
\hline & No think about & $\begin{array}{c}22 \\
25.9 \%\end{array}$ & $\begin{array}{c}8 \\
19.0 \%\end{array}$ & $\begin{array}{c}23 \\
33.3 \%\end{array}$ & $\begin{array}{c}3 \\
33.3 \%\end{array}$ & \\
\hline \multirow{4}{*}{$\begin{array}{c}\text { Ideal } \\
\text { number of } \\
\text { children }\end{array}$} & 0 & $\begin{array}{c}0 \\
.0 \% \\
\end{array}$ & $\begin{array}{c}0 \\
.0 \% \\
\end{array}$ & $\begin{array}{c}0 \\
.0 \% \\
\end{array}$ & $\begin{array}{c}0 \\
.0 \% \\
\end{array}$ & \multirow[t]{4}{*}{3.686} \\
\hline & 1 & $\begin{array}{c}4 \\
4.7 \%\end{array}$ & $\begin{array}{c}1 \\
2.4 \%\end{array}$ & $\begin{array}{c}3 \\
4.3 \%\end{array}$ & $\begin{array}{c}0 \\
0.0 \%\end{array}$ & \\
\hline & 2 & $\begin{array}{c}69 \\
81.2 \% \\
\end{array}$ & $\begin{array}{c}34 \\
81.0 \% \\
\end{array}$ & $\begin{array}{c}51 \\
73.9 \% \\
\end{array}$ & $\begin{array}{c}6 \\
66.7 \% \\
\end{array}$ & \\
\hline & Over 3 & $\begin{array}{c}12 \\
14.1 \%\end{array}$ & $\begin{array}{c}7 \\
16.7 \%\end{array}$ & $\begin{array}{c}15 \\
21.7 \%\end{array}$ & $\begin{array}{c}3 \\
33.3 \%\end{array}$ & \\
\hline \multirow{3}{*}{$\begin{array}{c}\text { Preferred } \\
\text { gender of the } \\
\text { child }\end{array}$} & Son & $\begin{array}{c}18 \\
21.2 \%\end{array}$ & $\begin{array}{c}8 \\
19.0 \%\end{array}$ & $\begin{array}{c}5 \\
7.2 \%\end{array}$ & $\begin{array}{c}1 \\
11.1 \%\end{array}$ & \multirow[t]{3}{*}{6.009} \\
\hline & Daughter & $\begin{array}{c}7 \\
8.2 \% \\
\end{array}$ & $\begin{array}{c}3 \\
7.1 \% \\
\end{array}$ & $\begin{array}{c}8 \\
11.6 \% \\
\end{array}$ & $\begin{array}{c}1 \\
11.1 \% \\
\end{array}$ & \\
\hline & $\begin{array}{l}\text { No specific preference for } \\
\text { the gender of the child }\end{array}$ & $\begin{array}{c}60 \\
70.6 \%\end{array}$ & $\begin{array}{c}31 \\
73.8 \%\end{array}$ & $\begin{array}{c}56 \\
81.2 \%\end{array}$ & $\begin{array}{c}7 \\
77.8 \%\end{array}$ & \\
\hline \multicolumn{2}{|r|}{ Total } & $\begin{array}{c}85 \\
100 \%\end{array}$ & $\begin{array}{c}42 \\
100 \%\end{array}$ & $\begin{array}{c}69 \\
100 \%\end{array}$ & $\begin{array}{c}9 \\
100 \%\end{array}$ & \\
\hline
\end{tabular}

$* \mathrm{p}<.05$

\section{CONCLUSION}

The objective of this study was review the difference in perception towards the current 'one household, two children' policy between the middle-aged group (age 40-59) and the elderly group (aged 60 or older) in China. The survey was conducted from June to August 2017 with the senile subjects in Shanghai, Xuzhou, Hefei, Suzhou, Chúzhōu, Wuhu, Maanshan, and Lingbi Xian. The 320 datasets for the senile generation and 305 for middle-aged generation were used in the final analysis.

The study shows that, unlike the elderly generation, the middle-aged group has a negative perception towards the 'one household, two children' policy. However, they do not think there should be two or more children per household. Rather, they think that there should be no limits imposed by the government on the number or gender of a couple's children and should leave it up to the couple themselves to make a choice.

Second, for the elderly generation of China, there was a significant difference in their perception towards the 'one household, two children' policy and 'preferred gender of children' depending on what the gender of the respondent's child was. The elderly with only daughters had a rather negative perception towards the policy, and their preferred gender for children was also 'sons.' This is in line with the more traditional view towards children held by the elderly generation. In traditional Chinese society, early marriage, early childbirth, and giving birth to many children, especially sons, would often be insurance against their later years. There was a higher preference for sons and an avoidance of daughters. This is associated with the mindset that the family name needed to be carried on by the son, the importance of saving face, and the value of labor and caregiving for the parents in their later years.

Third, the middle-aged group of China showed a significant difference in how they perceived the 'one household, two children' policy depending on the gender of their own children. Middle aged people with daughters had a more positive perception towards the policy. That is, compared to the middle-aged people with only sons, those with daughters seemed to want to give birth to sons through the one household, two children policy. 


\section{REFERENCES}

1. Y.H. Jia, "Talking about the problems and countermeasures of population aging under the family planning policy," The Farmers Consultant, vol. 65, no. 06, 2017, pp.160-165.

2. Z.Y. Tang, "On the heated discussion of population problems in China in 1957," Journal of Anhui University, vol. 253, no.5, 2005, pp. $112-116$.

3. X.H. Ma, and C. Sun, "The population fertility policy in 60 years of China," Social Sciences of Beijing, vol. 653, no. 4, 2011, pp. 46-47.

4. X. X. Liu, "Problems of providing for the childless and widowed elders in aging times and the improvement methods in assisting systems," Shanghai Urban Management, vol. 67, no. 6, 2014, pp. 12-13.

5. China National Bureau of Statistics, Statistical communique on national economic and social development in 2017, China National Bureau of Statistics, 2018

6. S. P. Li, "Analysis of the "Second Child Policy" in the current social situation," The Farmers Consultant, vol. 322, no. 15, 2018, pp. 260-261

7. S. H. He, "The change of farmers' concept of birth," Population and Development, vol. 431, no. 4, 2011, pp. 96-99.

8. W. Chen, and Y.Y. Duan, "Recent levels and trends of fertility in China," Population Research, vol. 45, no. 5, 2019, pp. 3-4.

9. Z. G. Guo, "The main features of the low fertility process in China: enlightenment from the results of the national $1 \%$ population sampling survey in 2015," Chinese Journal of Population Science, vol. 87, no.8, 2017, pp. 2-3.

10. Z. W. Chen, "Analysis on trend of fertility in China by age-period-cohort model," Journal of Zhengzhou University, vol. 63, no. 5, 2018, pp. 299-300.

11. G. Z. Wang, "China's population forecast methods and future population policies," FINANCIAL MINDS, vol. 25, no. 9, 2018 , $112-113$.

12. J. Xu, "Research on Chinese fertility concept: review and prospect," Population and Development, vol. 96, no. 6, 2018, pp. 78-83.

\section{AUTHORS PROFILE}

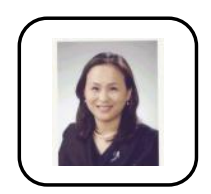

Yun-Jeong Kim, Ph.D., Ewha Womans University

Professor, Hanseo University

Chairman of health and welfare department of Hanseo

University, South Korea

Advisory Professor in Chungnam-do, Seosan-si, Hongseong-gun, Seosan-si, Dangjin-si, etc.

Publication: Gerontology, The elderly welfare, etc.

Research Areas: Elderly Care, Elderly Suicide,

Elder Abuse, Old Age Studies, Family Relations, etc.

Shuhu Chen, Ph.D, .Hanseo University

Lecturer, Anhui Normal University

Research Areas: Elderly Welfare, Senior Citizen

Education, etc. 